\title{
THE DYNAMIC LINK BETWEEN FINANCIAL DEVELOPMENT, TRADE OPENNESS AND FOREIGN DIRECT INVESTMENT: EMPIRICAL EVIDENCE FROM ETHIOPIA
}

\author{
Mekuanent Tesega \\ Dire Dawa University, Ethiopia
}

\begin{abstract}
Foreign direct investment (FDI) is an important source of external financing and an important factor for the economic development of a country. FDI is highly important especially for developing countries as it brings modern technologies and management skills in addition to narrowing the financial gaps. In this sense the knowledge of what determines FDI will have a tremendous significance. With the objective of empirically determining the long-run and short-run relationships between financial development, trade openness and FDI inflows in Ethiopia this study employed the ARDL model. The findings indicated that private sector credit, M2 and trade openness have a positive and significant influence on FDI inflows in the long-run while M2, and trade openness has a positive and significant influence on FDI in the short-run too. Current period private sector credit had no impact on FDI while the one period lag of it has a positive significant effect on FDI. Likewise, the causality test results disclose the presence of bi-directional causal relationships between private sector credit and FDI, and between M2 and trade openness. Furthermore, the findings indicate a one direction Granger cause from M2 to FDI. Policy makers are advised to consider trade openness and financial development measures in their quest for more FDI inflow.
\end{abstract}

Keywords: FDI, trade openness, financial development, ARDL, Ethiopia

\section{$\underline{\text { ARTICLE INFO }}$}

\section{Article History:}

Received: 6 January 2021

Accepted: 28 June 2021

Published: 31 August 2021

* Corresponding Author: Mekuanent Tesega. E-mail: mekuanent834@gmail.com 


\section{INTRODUCTION}

Walsh and $\mathrm{Yu}$ (2010) debate that there is a common understanding among policy makers that FDI is preferable for long-run growth compared to other types of capital inflows as FDI inflows bring management skills and advanced modern technology with them. It magnifies the importance of FDI inflows to the economy of host countries. Though it has an immense contribution, it is not easy to attract the required volume of inflows as all the countries in the world compete to take it home.

Ethiopia is aspiring to become a middle-income country by 2025 . Altaseb and Singh (2018) explained that sustainable economic growth is one of the most important macro-economic objectives of all countries and FDI is one of the key determinants of economic growth in Ethiopia. Though Ethiopia experienced a double-digit economic growth (about 10.3 percent as the World Bank data shows) from 2004 to 2019, from the mid of 1990s onwards the net FDI inflows relative to GDP have experienced ups and downs with the highest value in 2016. In achieving a middle-income economy with a sustainable economic growth of about 10 percent, Ethiopia would require broad and wide-based investments both through state and private investors which include investment by foreigners in the form of FDI.

According to Walsh and $\mathrm{Yu}$ (2010), foreign companies are more interested to invest in economies with a rapid growth rate and an economy with a higher growth rate has a higher advantage in attracting FDI inflows. While, Engidaw et al. (2020) argues that FDI has been considered as the vital source even for sustainable development for developing countries. For Getinet and Hirut (2005) the importance of FDI inflows in developing countries is important for developing countries since it provides essential resources that are not available such as advanced technologies and management skills.

Ethiopia has experienced an increasing FDI inflow especially after 2012 with fluctuations in some years. The highest ever FDI inflow to Ethiopia was in the year 2017 by attaining 4.017 billion dollars. As stated in 2011 by the Food and Agriculture Organization of the United Nations (FAO), Ethiopia has been absorbing a relatively higher FDI since the liberalization reforms of the economy which started in 1992 after the fall of the socialist 
Derg regime. In another context, even though the gross FDI inflows to the country were increasing and relatively high (amongst the top 5 countries in Africa in attracting FDI), the annual net inflows relative to the GDP levels were among the lowest, with an average value of 3.02 in the last ten years.

With regard to trade openness, Güriş and Gözgör (2015) defined trade openness as "an approach aiming to facilitate international free trade by the removal of the government control on the trade of goods and services". Foreign investors usually prefer to commit their resources in situations where there are favorable policies, good infrastructure facilities and markets. In other words, a favorable environment in foreign countries induces FDI inflow. Trade openness is one of the most important factors that enhance FDI inflow (Zaman et al., 2018). In support of this, Güriş and Gözgör (2015) claim that the most important effect of openness in a country is its contribution to attracting foreign capital. Starting from the 1980s many least developed countries accepted FDI as one important means to increase foreign capital. Countries tried to attract more FDI inflow because of their expectations that FDI contributes in different ways, such as technology transfer, backward and forward linkages, knowledge and skills transfer, increase in productivity, technical assistance, and opportunities for access to international markets (Tahmad \& Adow, 2018).

Empirically, different studies have shown the link between financial developments (FD) and trade openness with FDIs. As a demonstration of this, Islam et al. (2020); Desbordes and Wei (2017); Havi and Enu (2014) found a positive significant impact of financial development on FDI. On the other hand, Dellis (2018) and Tsaurai and Makina (2018) publicized the inconclusive results about the influence of financial development on FDI. In their studies, analyzing the link between trade openness and FDI inflows, Zaman et al. (2018); Güriş and Gözgör (2015); and Liargovas and Skandalis (2012) found out that the level of trade openness of countries is one of the factors influencing FDI inflow. However, Tahmad and Adow (2018) and Tsaurai (2015) stated that the link between trade openness and FDI is debatable.

Ethiopia is a poor country and its economy is highly reliant on the traditional agricultural sector. The agriculture sector constituted more than $33 \%$ of the GDP of Ethiopia in the year 2019. Besides, though it is an 
important engine for economic growth, many African and Latin American countries have low saving rates relative to their GDP (Patra et al., 2017). As the National Bank of Ethiopia (2020) report data shows, the average gross domestic saving from 2015/16 to 2019/20 was 22.4 percent. Moreover, Bukamo (2019) found the presence of a wide gap between gross domestic savings and gross domestic investment from 1981 to 2015, which indicates the need for more savings and other sources of investments. With no doubt, FDI will be an important source of finance for a country like Ethiopia in order to narrow the investment gap, reduce foreign currency shortages, and access modern technologies and know-how to invest in manufacturing, services and other important sectors.

The FDI data in Ethiopia shows that the country had almost a constant record of around zero net FDI inflows relative to GDP from 1996 to 2018. However, from the mid1990s onwards the net FDI inflows in reference to the GDP had increased showing the highest ever value in 2017 (about 5.7 percent of GDP). The world investment report (2018) showed that the FDI inflow share of Africa in two subsequent years - 2016 and 2017- was 2\% and 3\% respectively. Even though Africa has a small share as a continent, the Ethiopian Investment Commission (2019) reported that Ethiopia was one of the top African countries in attracting FDIs and the highest in East Africa by securing about 50 percent of the total FDI inflows to East Africa.

To further increase FDI inflow, Ethiopia has taken different policy measures. Melak (2018) indicated that with the objective of increasing the FDI inflow, Ethiopia took different measures such as economic liberalization and improvements in investment facilitation. Similarly, Gizaw (2015) stated that in order to fill the gap between savings and investment by attracting large FDIs to the country Ethiopia had made different policy reforms to create conducive investment conditions. To the knowledge of the researcher, no studies have been conducted in Ethiopia to see whether financial development (FD) and trade openness (TO) have affected FDI inflow as the theory and empirical studies in other countries suggest. Besides, in addition to the inconclusive nature of the findings of studies conducted in other countries, even those studies conducted do not consider these three variables altogether. Thus, this study will be helpful to fill the gap of the absence of empirical studies on the link between FD and TO and FDI and will show the nature of relationships of these variables in the Ethiopian context. 
The remainder of this paper is organized as follows. Part two presents the review of literature. Part three discusses the methodological issues of the study. Part four presents the results and discussion. Finally, part five is dedicated to the conclusions of the study.

\section{LITERATURE REVIEW}

\section{FDI in Ethiopia}

FDI mainly involves direct investments made by foreign countries or by foreign businesses and individuals (Win et al. 2017). According to the Ethiopian Investment Commission (2019), Ethiopia is one of the African countries that has been attracting a substantial amount of FDI especially after 2012. The report did attribute a relatively higher level of FDI to the country's double-digit fast-growing economy in the last decade to the shift in industrial policies. Even though there was a slight decline in the year 2018 relative to the ever highest FDI inflow year of 2017, Ethiopia absorbed about half of the total FDI inflow to all East African countries.

UNTCAD (2019) reported that Ethiopia has been the biggest FDI recipient among the East African countries. The FDI inflow to the country was from diverse countries and the investment covered the diversified sectors that included petroleum refining, mineral extraction, manufacturing and renewable energy. The report also showed that there was a positive prospect in attracting FDI in Ethiopia due to important factors such as economic liberalization, the improvements in investment facilitation measures, and the presence of developed special economic zones. However, there was a huge problem to be solved as well as Ethiopia ranked at 159 out of 190 countries in terms of the World Bank's ease of doing business index even though there was an attractive economic environment with the highest growth rate and the establishment of state of the art industrial parks (Ethiopian Investment Commission, 2019).

Ethiopia has important opportunities in increasing FDI inflow because of reasons that include, but are not limited to, the new administration preparing to privatize major state-owned enterprises (SOEs) in the telecoms, aviation, power, sugar, railway, and industrial parks sectors; the lifting of 
restrictions on the logistics sector and ratifying a law that permits PublicPrivate Partnerships (PPP) that opens up some sectors of the economy to foreigners to invest in; the normalization of the relationship with Eritrea which could have possibly helped to access an alternative port for Ethiopia; the country's approval of the African continental free trade area agreement and easing of visa requirements for African Union member countries; and Ethiopia is a country with a population of over 100 million, approximately two-thirds of whom are under the age 30, a national airline with 105 passenger connections, and a growing consumer market which is a key element in attracting FDI (US Department of State, 2019).

\section{Financial Development in Ethiopia}

Choong and Chan (2011) defined financial development as the improvement in different aspects such as quantity, quality and efficiency in financial intermediary services. Desbordes and Wei (2017) elucidate that financial developments of countries are important elements of the growth component of an economy (Desbordes \& Wei, 2017).

The financial sector in Ethiopia is mainly defined by banks, insurance companies and micro-finance institutions. The banking sector has experienced high growth, high returns and high profitability with no significant interruptions for more than a decade. The growth of the industry over the last decade has shown a very high annual rate of 28 percent for deposits, 31 percent growth in loans and a 22 percent annual profit growth rate (CEPHEUS, 2019). According to the annual reports' data of the national bank of Ethiopia, the insurance companies' number of branches grew from 221 to 568 in the last decade. Besides, the capital of the insurance industry experienced an annual average growth of about 29.6 percent in the last 10 years. It indicated the presence of significant growth of the insurance sector in Ethiopia. Micro finance institutions in Ethiopia, which mainly serve the rural population, represented only about 6 percent of the financial sector capital (WB, 2018). Though it is a low share, as the Ethiopian national bank data shows, MFIs showed a significant growth over the last decade. While the total capital of the micro finance institutions increased to 16.6 billion in 2019 from 2.4 billion birr in 2010, the total asset reached 83.5 billion birr in 2019 from 8 billion in 2010. The growth of micro finance institutions averaged 25.4 percent per year in the last 10 years. 
The Ethiopian financial sector is dominated by the banking industry and subjugated by a single state-owned commercial bank, the Commercial Bank of Ethiopia, low insurance penetration and an under-developed capital market. The capital market in Ethiopia mainly embraces Treasury bills (T-bills) and government bonds while the stock market is yet to be established (WB, 2018). The number of banks in Ethiopia is 18 of which 16 are privately owned and 2 state-owned banks. The total capital of the banking sector reached 110.9 billion birr and the significant portion of it (45.1 percent) is owned by a single state-owned bank, Commercial Bank of Ethiopia. In the same period, the total outstanding credit, not including the credits to the government, reached 605.4 billion birr. The private sector could get about $99 \%$ percent of all loans outstanding by private banks and about 49.7 percent of all outstanding loans of state owned banks. With regard to the insurance sector, to date, Ethiopia has 16 privately owned and 1 state-owned insurance company with a capital of 9 billion birr. About 68.8 percent of the total capital is owned by the single state-owned insurance company, the Ethiopian Insurance Corporation. Finally, there are 38 micro-finance institutions (MFIs) operating in Ethiopia which are mainly small sized (NBE, 2020). The Ethiopian financial industry is not open to international financial institutions and only local institutions with limited capacities are serving the market.

\section{Financial Development and FDI}

The relationship between FD and FDI are discussed in this sub-section, covering both the theoretical and empirical reviews.

\section{Theoretical Review on the Relationship between FD and FDI}

In theory, both the destination and source countries financial developments directly and indirectly influence FDI inflow to the host countries (Desbordes \& Wei, 2017; and Keykanloo et al., 2020).

\section{Direct Effects}

FDI investments usually involve high fixed costs and because of that the presence of developed financial intermediaries can contribute to cover parts of these costs from the host countries' financing sources (Donaubauer et al., 2016). The developed finance systems in destination countries are able to finance the FDIs when the source countries' institutions are unwilling 
to finance fully or requiring higher risk premiums. Higher host countries FD can have a positive direct effect on the FDI inflow (Desbordes \& Wei, 2017). Likewise, Desbordes and Wei (2017) argued that developed financial conditions can increase FDI inflow through external financing opportunities. In support of this theory, Khan and Khan (2019) clarified that FDs affect FDI inflow in various ways such as through the efficient allocation of assets by the intermediary financial institutions, reduction in transaction costs by allocating funds with lower fees, helping the decisions of the investors by providing the relevant information and reducing information asymmetry, and by maintaining favorable liquidity positions.

The source countries FD too can affect FDI flow to the host countries. The relatively undeveloped financial sectors in the host countries will be compensated by the finance form financially developed FDI source countries (Fauzel, 2016). In connection to this, Desbordes and Wei (2017) argued that higher source countries FD will exhibit a "positive direct external finance effect" on the FDI outflow volume. It is because the level of the FD determines a firm's access to external finance.

\section{Indirect Effects}

Desbordes and Wei (2017) and Keykanloo et al. (2020) claimed that FD in source and destination countries indirectly affects FDI inflow by supporting the economic environment. The better the financial system in the destination country the higher the positive indirect agglomeration effects on inward FDI. On the other hand destination countries' FD may have a negative indirect competition effect. However, the positive agglomeration effects are more likely to exceed the negative indirect competition effects (Desbordes \& Wei, 2017). Similarly, Donaubauer et al. (2016) explained that the financial markets development in destination countries can indirectly affect FDI inflow. Finally, with regard to the source countries, the FD of the source countries are known for the large number of producers and higher level of competition, thus firms will be more active for foreign expansion (such as in the form of FDI) rather than expanding their domestic investments (Desbordes \& Wei, 2017; and Keykanloo et al., 2020). 


\section{Empirical Review on the Relationship between FD and FDI}

Researches investigating the relationship between FD and FDI came to exist recently after a significant decline of FDI inflows observed due to the recent financial crisis (Hussain, 2016). Countries with higher investment demands compared to domestic savings may able to fill the gap and sustain economic growth by attracting foreign capital in form of FDI. However, empirical studies show that the positive influence of FDI on economic growth depends on the extent of the FD of the host countries (Jahfer \& Inoue, 2014). To this end, Hussain (2016) states that financial sector developments both in developing and emerging markets are decisive to enhance the FDI inflow in addition to their essential role towards the growth and expansion of the private sector.

By empirically exhibiting the positive strong influence of FD on FDI, Desbordes and Wei (2017) explained that deep financial systems in both the destination and source countries significantly increase the capital flows in the form of FDI. Similarly, Islam et al. (2020) had found a positive and significant role of FD in attracting FDI in 79 Belt and Road Initiative (BRI) partner countries. Havi and Enu (2014) undertook a study in Ghana for the period 1980 to 2012 using the simple dynamic ordinary least squares regression model and found a positive impact of FD on FDI. Likewise, Pradhan (2010) found a positive and statistically significant relationship between FD and FDI in India during 1970-2007 by employing Johansen's co-integration technique and the Error Correction Model (ECM). But, Dellis (2018) in 39 advanced and emerging economies and Tsaurai and Makina (2018) in the case of emerging markets found inconclusive results by applying the pooled OLS \& the two-step GMM estimator and modified dynamic panel threshold regression models respectively.

FD is measured by different proxies such as M2 to GDP ratio and credit to the private sector to the GDP ratio. Empirical studies have used these measures as a measure of FD in their study case areas. Moon (2017) and Ono (2017) used M2 to GDP ratio as a proxy to FD. On the other hand, Prasad et al. (2018); Duarte et al. (2017); and Paun et al. (2018) used credit to the private sector to GDP ratio, while Musamali et al. (2014); Badeeb and Lean (2017); Ololade (2014) and Al-Jarrah et al. (2012) used both the M2 to GDP ratio and credit to the private sector to GDP ratio to measure FD. 


\section{Trade openness and FDI}

Foreign investors usually prefer to invest their resources in situations where there are favorable policies, good infrastructure facilities, and markets. In other words, the foreign countries' favorable environment induces FDI inflow. In this regard, trade openness (TO) is considered to be one of the important factors that enhances FDI inflow (Zaman et al., 2018). Though Tahmad and Adow (2018) and Tsaurai (2015) indicated that the relationship between TO and FDI is debatable and mixed. Some empirical studies have shown the significant influence of TO in FDI inflow. Using the Fixed Effect and Pooled OLS techniques Zaman et al. (2018) studied the relationship between the openness of trade and FDI by taking three Asian countries, India, Iran, and Pakistan over the period 1982 - 2012. The result showed that TO openness influenced FDI inflow positively and significantly. According to Güriş and Gözgör (2015), Turkey had attracted multinational companies and has benefited by increasing FDI after the country's milestone decision in 1980 to open external trade. Similarly, Liargovas and Skandalis (2012) found out that TO have a significant influence in attracting FDI in the long run in Latin America, Asia, Africa, Eastern Europe, and the Commonwealth of Independent States during the period 1990 to 2008.

Brun and Gnangnon (2017) used a system of structural equations to see the contribution of TO towards financial flows on 37 least developed and 88 non-least developed countries over the period 1995-2012. The finding of this study showed that TO have no significant influence on FDI inflow over the entire 125 countries, while it exhibited a negative influence in the least developed countries and a positive impact in non-least developed countries on their FDI inflow.

Some studies investigated the link between TO and FDI in the African context. Cantah et al. (2016) used the Dynamic Panel Estimation Technique to analyze the connection between TO and FDI inflow in sub-Saharan Africa countries. The finding showed that TO influenced FDI inflow. Mohammed and Hayewa (2020) undertook a study to investigate the influence of TO on FDI in Sub-Sahara African Countries for the period 2000 to 2017. This study employed panel data analysis and found that TO have a positive and significant influence on FDI inflow in the region. Likewise, Tahmad and Adow (2018) investigated long-run equilibrium relationships between TO and FDI in Sudan covering the period 1990-2017. By using the Johansson 
Co-integration Technique the study found the presence of a long-run equilibrium relationship between TO and FDI in the case area.

\section{DATA AND METHODOLOGY}

This section presents the nature of the data and the methodology used in analyzing the link between FD, TO, and FDI. The study used secondary data collected from the United Nations Conference on Trade and Development (UNCTAD) and the National Bank of Ethiopia (NBE) reports covering the period 1980 to 2018. The dependent variable was FDI which was measured by the annual net FDI inflow. The financial development was represented by two different measuring variables, broad money (M2) to GDP ratio and private sector credit (PSC) to the GDP of the respective years. The broad money to GDP (M2/GDP) ratio is the most regularly used measure of FD (Musamali et al., 2014; Badeeb and Lean, 2017). Likewise, the National Bank of Ethiopia (2019) explained that the ratio of broad money to the GDP (M2/GDP) is an important financial deepening indicator.

Beck et al. (2000), as cited in Prasad (2018), argue that credits to the private sector is one of the frequently used and most appropriate methods to measure FD. These two methods were used as measures of FD as they indicate financial deepening and the involvement of the private sector in the economy.

The other explanatory variable, TO was measured by the commonly used method that is the ratio of import plus export against the GDP. The data corresponding to financial development measures and trade openness were collected from NBE, whereas the data on FDI were obtained from the UNCTAD.

For the econometric analysis, the Autoregressive Distributed Lag (ARDL) Model proposed by Pesaran et al. (2001) was applied. The ARDL model is a model where the dependent variable is explained by the current and lag values of the explanatory variables and the lag value of the dependent variable. In the ARDL model it is possible to tackle mis-specification \& autocorrelation problems and it helps to come up with more appropriate interpretable models (Ghouse et al., 2018). 
The ARDL has several advantages over other existing approaches which are: (1) it is sample size insensitive which means it can be applied with small sample cases; (2) it is applicable in the integration of I (0) or I (1) or mixed results of I (0) and I (1); (3) It allows different lag values for variables (Qamruzzaman \& Jianguo, 2018). In addition, Jakada and Mahmood (2020) and Qamruzzaman and Jianguo (2018) explained that the ARDL is appropriate to be applied in situations where the variables are integrated either order zero or order one or mixed results of order zero and order one, which may not be possible in other approaches. As the unit root tests contacted in this study witnessed mixed results with variables integrated at a level and the first difference, the ARDL was employed.

The simplest form of the ARDL $(p, q)$ Model can be represented as:

$$
\begin{aligned}
\operatorname{LnFDI}_{\mathrm{t}}=\alpha_{0} & +\sum_{\mathrm{i}=1}^{\mathrm{p}} \delta_{\mathrm{i}} \operatorname{LnFDI}_{\mathrm{t}-\mathrm{i}}+\sum_{\mathrm{i}=0}^{\mathrm{q}} \beta_{1} \operatorname{LnPSC}_{\mathrm{t}-\mathrm{i}}+\sum_{\mathrm{i}=0}^{\mathrm{q}} \beta_{2} \operatorname{LnM}_{\mathrm{t}-\mathrm{i}} \\
& +\sum_{\mathrm{i}=0} \beta_{3} \operatorname{LnTO}_{\mathrm{t}-\mathrm{i}}+\varepsilon_{\mathrm{t}}
\end{aligned}
$$

Where; is the dependent variable, $\mathrm{PSC}_{\mathrm{t}}$ (private sector credit), $\mathrm{M} 2_{\mathrm{t}}$ (broad money) and $\mathrm{TO}_{\mathrm{t}}$ (trade openness) are the independent variables, $p$ and $q$ represent the lag of dependent and independent variables, $\beta_{i} s$ are coefficients of independent variables, $\delta_{i}$ are the coefficients of the dependent variable, and $t$ represents a particular year.

Whereas, the error correction based the ARDL Model can be depicted as:

$$
\begin{aligned}
\Delta \operatorname{LnFDI}_{t}=\alpha_{0} & -\varphi\left(\operatorname{LnFDI}_{t-1}-\beta_{1} \operatorname{LnPSC}_{t-1}-\beta_{2} \operatorname{LnM}_{t-1}-\beta_{3} \operatorname{LnTO}_{t-1}\right) \\
& +\sum_{\substack{i=1 \\
q-1}}^{q-1} \theta_{i} \Delta \operatorname{LnFDI_{t-i}}+\sum_{i=0}^{q-1} \lambda_{i} \Delta L n P S C_{t-i}+\sum_{i=0}^{q-1} \lambda_{2} \Delta L n M 2_{t-i} \\
& +\sum_{i=0} \lambda_{3} \Delta \operatorname{LnTO}_{t-i}+\varepsilon_{t}
\end{aligned}
$$


Where; $\Delta \operatorname{Ln} \mathrm{FDI}_{t}=\operatorname{Ln} \mathrm{FDI}_{t}-\operatorname{Ln} \mathrm{FDI}_{t-1}, \varphi$ stands for the error correction term (speed of adjustments), $\beta_{i}$ represents the long-run coefficients, $\theta_{i}$ represent the short-run coefficient for lagged dependent variable and $\lambda_{i}$ are the short-run coefficients for lagged independent variables and $t$ indicates the year.

\section{RESULTS AND DISCUSSION}

Table 1 presents the descriptive statistics of the study that depicts the mean, standard deviation, minimum and maximum values of each variable.

Table 1: Summary Statistics

\begin{tabular}{lccccc}
\hline Variables & Observations & Mean & Std. Dev. & Maximum & Minimum \\
\hline FDI & 39 & 1.708 & 1.949 & 5.742 & -0.037 \\
M2/GDP & 39 & 29.78 & 5.744 & 41.177 & 16.473 \\
PSC/GDP & 39 & 15.64 & 13.44 & 52.235 & 1.756 \\
TO & 39 & 32.078 & 11.177 & 51.056 & 12.242 \\
\hline
\end{tabular}

The summary statistics as in Table 1 presents the descriptive statistics values of all the variables involved. The net FDI inflow showed a mean, maximum and minimum value of $1.708,5.742$ and -0.037 respectively. The negative net FDI inflow relative to the respective years GDP were observed during the 1980s, the lowest being in 1983 (-0.037). Ethiopia had experienced one of the worst famines and hunger crises during the 1980s due to devastating drought and civil wars. In addition, Ethiopia faced mass starvation during 1972/73, 1984/85, 1987, and 1998-2000 which affected the lives of hundreds of thousands of people and livestock (Alemayehu, 2001). The highest FDI inflow against the same year GDP was witnessed in the year 2016. The expansion of industrial zones and industrial policy changes are believed to be the main contributors. The relatively higher growth of FDI inflow after 2012 to 2018 was mainly attributed to the double-digit fast economic growth of the country and its industrial policy (Ethiopian Investment Commission, 2019).

The ratio of broad money (M2) to GDP ratio as a FD indicator showed a mean of 29.78 over the years covered in this study. The maximum and 
minimum M2/ GDP scores were 41.177 and 16.47 respectively. The other FD indicator, which is private sector credit over GDP, also showed a mean of 15.64 with the maximum and minimum observations of 52.235 and 1.756 respectively. Finally, TO in Ethiopia measured as a ratio of import plus export aggregate over GDP displayed a mean of 32.078 with maximum and minimum values of 51.056 and 12.24 respectively.

\section{Important Model Diagnostics Tests}

Table 2 summarizes the important econometric model tests that show the appropriateness and soundness of the model and the model results.

Table 2: Model Diagnostics Tests

\begin{tabular}{|l|c|}
\hline \multicolumn{1}{l|}{$\mathrm{R}^{2}$} & 0.870 \\
{$\left[\right.$ [adj-R $\left.{ }^{2}\right]$} & {$[0.807]$} \\
\hline F-test & 13.962 \\
[P-Value] & {$[0.000]$} \\
\hline Breusch-Godfrey Serial Correlation LM Test: & 1.173 \\
[P-Value] & {$[0.329]$} \\
\hline Breusch-Pagan-Godfrey Heteroskedasticity Test & 0.739 \\
[P-Value] & {$[0.692]$} \\
\hline Ramsey RESET Test & 0.051 \\
[P-Value] & {$[0.824]$} \\
\hline Stability tests: & \\
CUSUM test & Stable $^{\mathrm{a}}$ \\
CUSUM of square tests & Stable $^{\mathrm{b}}$ \\
\hline
\end{tabular}

aThe graphical test of the CUSUM stability test is depicted in graph 1

${ }^{\mathrm{b}}$ The graphical test of the CUSUM squares stability test is depicted in graph 2

\section{Model Stability Tests}

As there is volatility of the time variables, stability tests for the ARDL Model is required to avoid mis-specifications in the functional form (Kim, 2020). In this study, the cumulative sum (CUSUM) and the cumulative sum of squares (CUSUMSQ) tests were applied to ensure the stability of the selected ARDL Model. The CUSUM and CUSUMSQ tests are important techniques to show the stability of the parameters in the model (Pesaran et al., 2001). In both the CUSUM and CUSUMSQ test graph, if the blue lines do not cross the red lines (critical value lines), it implies the stability of the ARDL model (Sultanuzzaman et al., 2018; Duarte et al., 2017). Since the 
blue line of the CUSUM and CUSUMSQ test graphs in Graphs 1 and 2 respectively laid within the red lines, it confirmed the stability of the model and the reliability of the parameters estimated.

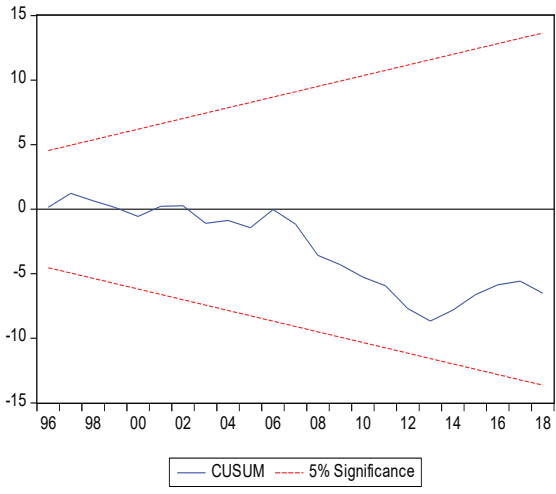

Graph 1: CUSUM Stability Tests

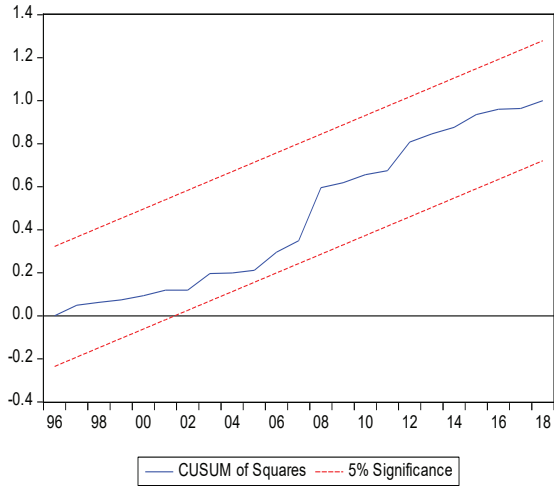

Graph 2: CUSUM of Squares Stability Test

\section{Unit Root Test}

It is very essential to take the test of unit root to make sure that none of the variables are stationary up to two or I (2) as the F-statistics values will not be valid in determining the co-integration in I (2) (Jakada \& Mahmood, 2020). As different stationary models imply different predictions the use of unit root tests as a diagnostic tool in order to choose the most appropriate model is indispensable (Diebold \& Kilian, 2000). In addressing this issue, the Dickey-Fuller test is one of the most common unit root tests in determining the integration order of analyzing time series (Arltová \& Fedorová, 2016). In this study, the Dickey-Fuller Unit Root Test was applied and the results of the test are presented in Table 3. 
Table 3: A Unit Root Test Results

\begin{tabular}{ccccc}
\hline \multicolumn{5}{c}{ ADF unit-root tests } \\
Variables & & Intercept & $\begin{array}{c}\text { Intercept }+ \\
\text { trend }\end{array}$ & $\begin{array}{c}\text { Order of } \\
\text { integration }\end{array}$ \\
\hline \multirow{2}{*}{ LnFDI } & $\mathrm{I}(0)$ & $-1.662[0.442]$ & $-2.875[0.181]$ & \\
\hline \multirow{2}{*}{ Ln(PSC/ } & $\mathrm{I}(1)$ & $-5.818[0.000]$ & $-5.734[0.000]$ & $\mathrm{I}(1)$ \\
GDP) & $\mathrm{I}(1)$ & $-3.010[0.043]$ & $-3.745[0.031]$ & $\mathrm{I}(0)$ \\
\hline \multirow{2}{*}{ Ln(M2/ } & $\mathrm{I}(0)$ & $-3.013[0.043]$ & $-2.483[0.334]$ & \\
GDP) & $\mathrm{I}(1)$ & $-5.083[0.000]$ & $-5.074[0.001]$ & $\mathrm{I}(1)$ \\
\hline \multirow{2}{*}{ LnTO } & $\mathrm{I}(0)$ & $-1.151[0.685]$ & $-1.326[0.866]$ & \\
\hline
\end{tabular}

Note: I (0) and I (1) represent at levels and first differences respectively. The critical values of the ADF test at $1 \%, 5 \%$ and $10 \%$ levels are: $-3.621,-2.943$ and -2.610 for intercept and $-4.227,-3.537$ and -3.200 for both intercept and trend respectively.

As shown in Table 3 one variable was stationary at a level while the rest three variables were stationary at first difference. From this, using the ARDL Model for the sake of the empirical analysis is appropriate.

\section{ARDL Bounds Test}

The ARDL bound test is applied to see the long-run co-integration in the model. In the Bounds Test, if the F-statistics falls outside the critical value bounds, conclusive inferences can be drawn. If the F-statistics value is greater than the upper bound of critical values, it implies the presence of long-run co-integration in the model. When the F-statistics is lower than the lower bound value it shows that the long-run integration does not exist (Pesaran et al., 2001). Before applying the ARDL Bound Testing, we need to make sure that all the variables are integrated either in I $(0), \mathrm{I}(1)$ or both, but none of them integrated at I (2) (Qamruzzaman \& Jianguo, 2018). The Dickey-Fuller Unit Root Test (Table 3) revealed that the variables were integrated at a level and first difference that permitted the use of the ARDL bound test. Table 4 presents the ARDL Bounds Test results $(1,0,3,4)$ of the study. 
Table 4: ARDL Bounds Test

\begin{tabular}{ccc}
\hline $\begin{array}{c}\text { Test Statistic } \\
\text { F-statistic }\end{array}$ & Value & \\
& 5.052 & \\
& $\begin{array}{c}\text { Critical Value Bounds } \\
\text { Lower Bound }\end{array}$ & Upper Bound \\
$10 \%$ & 2.72 & 3.77 \\
$5 \%$ & 3.23 & 4.35 \\
$2.5 \%$ & 3.69 & 4.89 \\
$1 \%$ & 4.29 & 5.61 \\
\hline
\end{tabular}

Note: The null hypothesis is no long- run relationships exist

Because the calculated F-statistics value of 5.052 was greater than the upper bound value of 4.35 at the $5 \%$ significance level, the null hypothesis of no long-run relationship was rejected. Since the Bound Test confirmed the presence of co-integration among the variables and the unit root test result of stationary at a level and first difference, the ARDL Model was applied to see the link between the variables.

\section{The Long-Run and Short-Run Analysis}

In this sub-topic, the empirical results obtained from the ARDL longrun and short-run co-integration were analyzed. Table 5 provides the longrun coefficients while Table 6 presents the short-run coefficient estimates.

Table 5: ARDL Long-Run Co-Integration Results

\begin{tabular}{cccc}
\hline Variable & Coefficient & Std. Error & Prob. \\
\hline LnTO & 0.871769 & 0.167562 & 0.0000 \\
Ln(PSC/GDP) & 0.636885 & 0.127292 & 0.0000 \\
Ln(M2/GDP) & 0.858555 & 0.497873 & 0.0980 \\
C & -6.657761 & 1.856465 & 0.0016 \\
\hline
\end{tabular}

The long-run estimates of the ARDL $(1,0,3,4)$ Model employed are shown in Table 5. The results provide a positive significant relationship of both TO and private sector credit (PSC) with the FDI inflow at the 1\% significance level. M2 (broad money) implied a positive long-run significant relation to FDI at the $10 \%$ significance level. 
As the coefficient values of the test results show, if TO increases by $1 \%$, the FDI will increase by $0.87 \%$. Trade openness is an engine of economic growth and it affects FDI inflow positively (Zaman et al., 2018). It attests that $\mathrm{TO}$ is one of the significant factors foreign investors would like to consider if they are deciding on investing abroad. The result is consistent with the findings of Liargovas and Skandalis (2012); Güriş and Gözgör (2015); and Zaman et al. (2018). Concerning the PSC/GDP ratio, when it increases by $1 \%$, the FDI inflow increases by $0.65 \%$ that shows the direct relationship between the variables. A higher the ratio of private sector credit to GDP implies a higher FD (Hassan et al., 2011). This finding implies that higher private sector credits mean better FD. In turn higher FD promotes better financial services including credit access and it helps to attract FDI. The finding is in line with the findings of Desbordes and Wei (2017); Hussain (2016) and Korgaonkar (2012).

Similarly, if M2/GDP increases by $1 \%$, the FDI inflow towards this country increases by $0.85 \%$. The larger value of the M2 to GDP ratio indicates a higher level of FD in a country (Musamali et al., 2014). It implies that higher FD, measured as M2/GDP, is among the important attracting forces of FDI. The result is in line with the findings of Hussain (2016) and Pradhan (2010).

Table 6: ARDL Short-Run Co-Integration Results

\begin{tabular}{cccc}
\hline Variable & Coefficient & Std. Error & Prob. \\
\hline DLn(TO) & 0.657705 & 0.178925 & 0.0013 \\
DLn(PSC/GDP) & -0.509736 & 0.749649 & 0.5033 \\
DLn(PSC/GDP(-1)) & 2.059671 & 1.085077 & 0.0703 \\
DLn(PSC/GDP(-2)) & -1.225263 & 0.662045 & 0.0771 \\
DLn(M2/GDP) & 2.565914 & 0.865299 & 0.0069 \\
DLn(M2/GDP(-1)) & -0.703065 & 1.175018 & 0.5555 \\
DLn(M2/GDP_(-2)) & -0.357860 & 0.899302 & 0.6944 \\
DLn(M2/GDP(-3)) & 1.886558 & 0.628973 & 0.0064 \\
CointEq(-1) & -0.754448 & 0.165843 & 0.0001 \\
\hline
\end{tabular}


Table 6 depicts the short-run estimates of the ARDL Model. The results indicate that TO and broad money revealed a positive significant influence on FDI inflows at the 1\% significance level. If the current year TO and M2 increases by $1 \%$, the FDI level increases by $0.65 \%$ and $2.56 \%$ respectively. Whereas, only one-year lag value of private sector credit showed a positive short-run significant impact on FDI at the 5\% significance level.

The equilibrium error correction coefficient (ECM) had the right sign (negative) and was statistically significant at the $1 \%$ level. The ECM implies how fast short-term disequilibrium is adjusted to the long-run equilibrium (Duarte et al., 2017). The value of -0.754 indicated that the short-run disequilibrium that occurred were adjusted to long-run equilibrium at about $75.4 \%$ a year.

\section{Causality Tests}

In this part, the causal relations between the variables were examined by using the Granger causality test and the results are presented in Table 7. The Granger causality test (Granger, 1969) is an important test to see if there is a causal linkage between the variables.

Table 7: Granger Causality - Wald Tests

\begin{tabular}{|c|c|}
\hline Direction & P-value \\
\hline $\begin{array}{c}\mathrm{Ln}(\mathrm{PSC} / \mathrm{GDP}) \rightarrow \ln \mathrm{FDI} \\
\mathrm{PSC} / \mathrm{GDP} \rightarrow \operatorname{Ln}(\mathrm{M} 2 / \mathrm{GDP}) \\
\mathrm{Ln}(\mathrm{PSC} / \mathrm{GDP}) \rightarrow \mathrm{LnTO}\end{array}$ & $\begin{array}{l}0.095 \\
0.510 \\
0.795\end{array}$ \\
\hline $\begin{array}{c}\operatorname{Ln}(\mathrm{M} 2 / \mathrm{GDP}) \rightarrow \operatorname{InFDI} \\
\operatorname{Ln}(\mathrm{M} 2 / \mathrm{GDP}) \rightarrow \operatorname{Ln}(\mathrm{PSC} / \mathrm{GDP}) \\
\operatorname{Ln}(\mathrm{M} 2 / \mathrm{GDP}) \rightarrow \operatorname{LnTO}\end{array}$ & $\begin{array}{l}0.089 \\
0.447 \\
0.015\end{array}$ \\
\hline $\begin{array}{c}\mathrm{LnTO} \rightarrow \text { LnFDI } \\
\mathrm{LnTO} \rightarrow \text { Ln(PSC/GDP) } \\
\text { LnTO } \rightarrow \text { Ln(M2/GDP })\end{array}$ & $\begin{array}{l}0.712 \\
0.292 \\
0.048\end{array}$ \\
\hline $\begin{array}{l}\text { LnFDI } \rightarrow \text { Ln(PSC/GDP }) \\
\text { InFDI } \rightarrow \text { Ln(M2/GDP) } \\
\text { LnFDI } \rightarrow \text { LnTO }\end{array}$ & $\begin{array}{l}0.027 \\
0.933 \\
0.509\end{array}$ \\
\hline
\end{tabular}


The Pairwise Granger Causality test was conducted to investigate the presence and direction of the causal relationship between broad money, private sector credit, trade openness and FDI. Table 7 shows the presence of a two-way causality between private sector credit and FDI. This indicates the past value of both variables will have a significant linear causal impact on the current value of the other. Similarly, with the same implication, the test result confirmed the existence of two-directional Granger causality between broad money (M2) and TO. On the other hand, broad money (M2) Granger causes the FDI inflow in one direction. The implication is that the past value of broad money has a significant linear impact on the current period net FDI inflow.

\section{CONCLUSION AND POLICY DIRECTIONS}

The study investigated the link between FD and TO and FDI in Ethiopia. In achieving the objective of investigating the relationship, the time series data of about 39 consecutive years were used. The ARDL Model was employed to determine the link between the dependent and the explanatory variables. This study used two commonly known FD measures, private sector credit and broad money (M2).

The test results revealed that the FD measures, private sector credit, and M2, had a positive significant influence on FDI inflow in Ethiopia in the long-run. As the FD improved in Ethiopia in the long-run due to the increases in private sector credits and an increase in broad money in the economy, the FDI inflow also increased. Similarly, TO was found to be a significant factor in affecting FDI inflow in the long-run. From this, it can be concluded that when a country's trade becomes more open, the FDI inflow from abroad also increases and it supports the argument that investors are attracted by an open trade environment when they make their investment decisions.

In the short-run, M2 and trade openness were found to have a positive significant effect on FDI inflow. From this we can understand that the increase in broad money and an improvement in TO affects the current periods FDI inflow positively. However, private sector credit was not a significant factor influencing FDI inflow in the short-run. A one-year 
lag value of private sector credit showed a positive significant effect in influencing FDI inflow. The conclusion is that it takes at least a year before the credits to the private sector affects the FDI inflow as the result implies. It might be because of the reason that the taking of credit by the private sector may not immediately produce economic outputs as the credits secured so as to influence FDI inflow.

With regard to the causality analysis, there were bi-directional Granger causes between private sector credit and FDI and between M2 and trade oneness. However, the output also indicated that M2 is Granger causal for FDI. Since both the private sector credit and M2 Granger cause the FDI inflow in Ethiopia, we can draw an understanding that the policies and different actions in operation concerning private sector credit and M2 will cause the volume of FDI to change.

Based on the results, policy-makers and other concerned parties are advised to consider FD in their efforts to increase FDI inflow. Measures should be taken to increase credits to the private sector and improve the volume of M2 in the financial market that will help to attract more FDI. In addition, the government should create an open trade environment in order to absorb more FDI. Thus, the country's low rank in the World Bank's Ease of Doing Business Index can be improved by reducing bureaucracy and policy issues and then the FDI inflow can be further increased.

\section{REFERENCES}

African Development Bank (2021). African economic outlook 2021 - From debt resolution to growth: The road ahead for Africa. Retrieved from https://www.afdb.org/en/knowledge/publications/african-economicoutlook

African Development Bank Group (2015). Federal Democratic Republic of Ethiopia Country Strategy Paper 2016-2020. EARC Department.

Al-Jarrah, I., Al-Zu'bi, M. F., Jaara, O., \& Alshurideh, M. (2012). Evaluating the impact of financial development on economic growth in Jordan. International Research Journal of Finance and Economics, 94, 123-139. 
Altaseb, A., \& Singh, K. (2018). Economic growth determinants in Ethiopia: A literature survey. International Journal of Research and Analytical Reviews, 5(4), 326-336.

Arltová, M., \& Fedorová, D. (2016). Selection of unit root test on the basis of length of the time series and value of AR(1) parameter. Statistika, 96(3), 47-64.

Badeeb, R. A., \& Lean, H. H. (2017). The determinants of financial development in the Republic of Yemen: Evidence from the principal components approach. Capital Market Review, 25(2), 32-48.

Brun, J. F., \& Gnangnon, S. K. (2017). Does trade openness contribute to driving financing flows for development? (No. ERSD-2017-06). WTO Staff Working Paper.

Bukamo, Z. (2019). The causal relationship between saving and investment in Ethiopia. Global Scientific Journals, 7(4).

Cantah, G. W., Brafu-Insaidoo, G. W., Wiafe, E. A., \& Adams, A. (2018). FDI and trade policy openness in Sub-Saharan Africa. Eastern Economic Journal, 44(1), 97-116. 10.1057/eej.2016.910.1057/eej.2016.9

CEPHEUS. (2019). Ethiopia's Banking Sector: Sector Research Ethiopia. CEPHEUS Research \& Analysis. Retrieved from https://cepheuscapital. com/wp-content/uploads/2019/01/Banking-Sector-Paper.pdf

Choong, C., \& Chan, S. (2011). Review financial development and economic growth: A review. African Journal of Business Management, 5(6), 2017-2027. doi:10.5897/ajbm10.772

Desbordes, R., \& Wei, S. (2017). The effects of financial development on foreign direct investment (NBER Research Working Paper Series, No. 23309). Retrieved from http://www.nber.org/papers/w23309

Diebold, F. X., \& Kilian, L. (2000). Unit-root tests are useful for selecting forecasting models. Journal of Business \& Economic Statistics, 18(3), 265-273. 
Donaubauer, J., Neumayer, E., \& Nunnenkamp, P. (2016). Financial market development in host and source countries and its effects on bilateral FDI (No. 2029). Kiel Working Paper.

Duarte, L. D. R. V., Kedong, Y., \& Xuemei, L. (2017). The relationship between FDI, economic growth and financial development in Cabo Verde. International Journal of Economics and Finance, 9(5), 132-142. doi:10.5539/ijef.v9n5p132

Economic Commission for Latin America and the Caribbean (ECLAC) (2015). Foreign direct investment in Latin America and the Caribbean. United Nations Publication. Santiago, Chile. Retrieved from LC/ G.2641-P, S1500534_en.pdf

Engidaw, S., Zhu, W., Lu, Y., \& Wang, Z. (2020). Does Chinese inward foreign direct investment improve the productivity of domestic firms? Horizontal linkages and absorptive capacities: Firm-level evidence from Ethiopia. Journal of Sustainability, 12(7), 3023. doi.org/10.3390/ su12073023

Ethiopian Investment Commission (2019). Trends in FDI flows to Ethiopia. Ethiopian investment report. EIC-Investment-Report-2019.pdf

FAO (2011). Foreign agricultural investment country profile of Ethiopia. FAO Investment Policy Support, Rome, Italy.

Fauzel, S. (2016). Modeling the relationship between FDI and financial development in small island economies: A PVAR approach. Theoretical Economics Letters, 6, 367-375. http://dx.doi.org/10.4236/ tel.2016.63041

Getinet, A., \& Hirut, A(2005). Determinants of foreign direct investment in Ethiopia: A time-series analysis. Paper presented at the 4th International Conference on the Ethiopian Economy, 10-12 Jun 2006, Addis Ababa, Ethiopia.

Ghouse, G., Khan, S., \& Rehman, A. (2018). ARDL model as a remedy for spurious regression: Problems performance and prospectus (MPRA 
Paper No. 83973). Retrieved from https://mpra.ub.uni-muenchen. de/83973/

Gizaw, D. (2015). The impact of foreign direct investment on economic growth: The case of Ethiopia. Journal of Poverty, Investment and Development, 15, 34-47.

Güriş, S., \& Gözgör, K. (2015). Trade openness and FDI inflows in Turkey. Applied Econometrics and International Development, 15(2), 53-62.

Hassan, M. K., Sanchez, B., \& Yu, J. S. (2011). Financial development and economic growth in the organization of Islamic conference countries. Journal of King Abdul Aziz University: Islamic Economics, 24(1), 145-172.

Havi, E. D. K., \& Enu, P. (2014). The effect of fiscal policy and monetary policy on Ghana's economic growth: Which policy is more potent. International Journal of Empirical Finance, 3(2), 61-75.

Hussain, S. (2016). Financial development and foreign direct investment: The case of Middle East and North African (MENA) developing nations (MPRA Paper, No. 82013). Retrieved from https://mpra.ub.unimuenchen.de/82013/

Islam, M. A., Khan, M. A., Popp, J., Sroka, W., \& Oláh, J. (2020). Financial development and foreign direct investment — The moderating role of quality institutions. Sustainability, 12(9), 3556.

Jahfer, A., \& Inoue, T. (2014). Financial development, foreign direct investment and economic growth in Sri Lanka. International Journal of Economic Policy in Emerging Economies, 7(1), 77-93. https://ideas. repec.org/a/ids/ijepee/v7y2014ilp77-93.html

Jakada, A. H., \& Mahmood, S. (2020). An asymmetric effect of economic growth, foreign direct investment and financial development on the quality of environment in Nigeria. The Journal of Management Theory and Practice (JMTP), 5-13. http://dx.doi.org/10.37231/jmtp.2020.1.1.6 
Keykanloo, M., Hosseini, S., Jazeh, K., \& Askari, A. (2020). The effect of financial development on foreign direct investment. Iranian Economic Review, 24(4), 885-906.

Khan, H., \& Khan, U. (2019). Financial development and FDI inflows in China (No. 2019-54). Economics Discussion Papers. Kiel Institute for The World Economy. Retrieved from http://www.economics-ejournal. org/economics/discussionpapers/2019-54

Kim, S. (2020). The effects of foreign direct investment, economic growth, industrial structure, renewable and nuclear energy, and urbanization on Korean greenhouse gas emissions. Sustainability Journal, 12(4), 1625. $10.3390 /$ su 12041625

Korgaonkar, C. (2012). Analysis of the impact of financial development on foreign direct investment: A data mining approach. Journal of Economics and Sustainable Development, 3(6), 70-78.

Liargovas, P., \& Skandalis, K. (2012). Foreign direct investment and trade openness: The case of developing economies. Social Indicators Research, 106(2), 323-331. 10.1007/s11205-011-9806-9

Melak, A. (2018). The contribution of foreign direct investment for economic growth of Ethiopia: Time series analysis. International Journal of Contemporary Research and Review, 9(2). doi.org/10.15520/ ijcrr/2018/9/01/414

Mohammed, B. S., \& Hayewa, S. Y. U. (2020). Impact of trade openness on foreign direct investment in Sub Saharan Africa countries. MSR Working Paper Series, 003-2020. http://dx.doi.org/10.2139/ssrn.3730684

Moon J. (2017). Financial development and economic growth: Evidence from South Korea between 1961 and 2013. International Journal of Management, Economics and Social Sciences, 6(2), 89-106.

Musamali, R. A., Nyamongo, E. M., \& Moyi, E. D. (2014). The relationship between financial development and economic growth in Africa. Research in Applied Economics, 6(2), 190-208. 
Ololade, O. (2014). Financial development and economic growth nexus in Nigeria. Global Journal of Commerce \& Management Perspectives, 3(5), 231-241.

Ono, S. (2017). Financial development and economic growth nexus in Russia. Russian Journal of Economics, 3, 321-332

Patra, S., Murthy, S., Kuruva, M., \& Mohanty, K. (2017). Revisiting the causal nexus between savings and economic growth in India: An empirical analysis. Economia, 18(3), 380-391.

Paun, C., Musetescu, R., Topan, V. and Danuletiu, D. (2019). The Impact of Financial Sector Development and Sophistication on Sustainable Economic Growth. Sustainability, 11, 10.3390/su11061713

Pesaran, M., Shin, Y., \& Smith, R. (2001). Bounds testing approaches to the analysis of level relationships. Journal of Applied Econometrics, 16(1), 289-326. 10.1002/jae.616

Pradhan, R. (2010). Financial deepening, foreign direct investment and economic growth: Are They cointegrated. International Journal of Financial Research, 1(1), 37-43. doi:10.5430/ijfr.v1n1p37

Prasad, B. (2018). Financial development and economic growth: Evidence from a panel of 16 African and non-African low-income countries. Cogent Economics \& Finance, 6(1), 1-17, 10.1080/23322039.2018.1449780

Qamruzzaman, M., \& Jianguo, W. (2018). Investigation of the asymmetric relationship between financial innovation, banking sector development, and economic growth. Quantitative Finance and Economics, 2(4), 952-980. 10.3934/QFE.2018.4.952

Sultanuzzaman, M. R., Fan, H., Akash, M., Wang, B., \& Shakij, U. S. M. (2018). The role of FDI inflows and export on economic growth in Sri Lanka: An ARDL approach. Cogent Economics \& Finance, 6(1), 1518116. https://doi.org/10.1080/23322039.2018.1518116 
Tahmad, A., \& Adow, A. (2018). The impact of trade openness on foreign direct investment in Sudan by sector in the 1990-2017 period: An empirical analysis. Economic Annals, 172, 14-21.

Tsaurai, K. (2015). Trade openness and FDI in Zimbabwe: What does data tell us? Corporate Ownership \& Control, 12(4), 303-311. 10.22495/ cocv12i4c2p6

Tsaurai, K., \& Makina, D. (2018). The impact of financial sector development on foreign direct investment: An empirical study on minimum threshold levels. Journal of Economics and Behavioral Studies, 10(5), 244-254.

United Nations Conference on Trade and Development (UNTCAD). (2019). Chapter II - Regional Trends. World Investment Report - Special Economic Zones. Retrieved from https://unctad.org/system/files/officialdocument/WIR2019_CH2.pdf

US Department of State (2019). 2019 Investment Climate Statements Report: Ethiopia. Retrieved from https://www.state.gov/reports/2019investment-climate-statements/ethiopia/

Walsh, M. J. P., \& Yu, J. (2010). Determinants of foreign direct investment: A sectoral and institutional approach (International Monetary Fund $\mathrm{WP} / 10 / 187)$.

Win, H. H. H., Ichihashi, M., Kaneko, S., \& Goto, D. (2017). Relationship between financial development and foreign direct investment. IDEC DP2 Series, 7(2), 1-24.

World Bank (WB). (2017). Investment policy and promotion diagnostics and tools: Maximizing the potential benefits of foreign direct investment (FDI) for competitiveness and development (English). Washington, D.C.: World Bank Group. Retrieved from http://documents.worldbank. org/curated/en/666341500008847215/Maximizing-the-potentialbenefits-of-foreign-direct-investment-FDI-for-competitiveness-anddevelopment 
World Bank (WB). (2018). Ethiopia economic update: The inescapable manufacturing services nexus: Exploring the potential of distribution services (English). Washington, D.C.: World Bank Group. Retrieved from http://documents.worldbank.org/curated/en/8117915264471200 21/The-inescapable-manufacturing-services-nexus-exploring-thepotentialof-distribution-services

Zaman, Q., Donghui, Z., Yasin, G., Zaman, S., \& Imran, M. (2018). Trade openness and FDI inflows: A comparative study of Asian countries. European Online Journal of Natural and Social Sciences, 7(2), 386-396. 